Article

\title{
Increasing Abundance of Silky Sharks in the Eastern Indian Ocean: Good News or a Reason to be Cautious?
}

\author{
Benaya Meitasari Simeon ${ }^{1}$, Efin Muttaqin ${ }^{1}$, Ulfah Mardhiah ${ }^{1}$, Muhammad Ichsan ${ }^{1}$, \\ Dharmadi ${ }^{2}$, Andhika Prima Prasetyo ${ }^{2}$, Fahmi $^{3}$ and Irfan Yulianto ${ }^{1,4, *}$ \\ 1 Wildlife Conservation Society-Indonesia Program, Jalan Tampomas No.35, Babakan, Bogor Tengah, \\ Bantarjati, Bogor Utara, Kota Bogor, Jawa Barat 16151, Indonesia; bsimeon@wcs.org (B.M.S.); \\ emuttaqin@wcs.org (E.M.); umardhiahsir@gmail.com (U.M.); michsan@wcs.org (M.I.) \\ 2 Center for Fisheries Research, Indonesia Ministry of Marine Affairs and Fisheries, Jl. Pasir Putih II, \\ Ancol Timur, Jakarta 14430, Indonesia; dharmadi.shark@gmail.com (D.); dhika.fishery@gmail.com (A.P.P.) \\ 3 Indonesian Institute of Sciences, Jl. Pasir Putih I, Ancol Timur, Jakarta 14430, Indonesia; \\ fahmi_lipi@yahoo.com \\ 4 Faculty of Fisheries and Marine Sciences, Bogor Agrilcultural University, Kampus IPB Darmaga, \\ Bogor 16680, Indonesia \\ * Correspondence: iyulianto@wcs.org or iyu@psp-ipb.org
}

Received: 8 June 2018; Accepted: 11 July 2018; Published: 18 July 2018

\begin{abstract}
The silky shark (Carcharhinus falciformis) is the most common shark landed in Indonesian waters, including in the Indian Ocean. However, even though they are frequently caught, there is a lack of information on the population and abundance of silky sharks in the Indian Ocean. Cilacap and Tanjung Luar are two of Indonesia's shark fishery hotspots, both located on the edge of the Indian Ocean, which is a part of the Indonesian Fisheries Management Area (FMA) 573. The fishers from both places usually have fishing grounds in that particular fisheries management area. This research aims to update the abundance, and to investigate the factors, which influence catches of silky shark in the FMA 573 based on monthly enumeration during 2015-2016. This study found that standardized catch-per-unit-effort (CPUE) or abundance indices of silky shark in the Indonesian FMA 573 increased from 2015 to 2016. We suggested that fish immigration and decreasing fishing pressure may affect the fish abundance. Fisheries management is required to regulate the fishing pressure, such as controlling the number of boats/licenses and the number of trips or fishing gear, as well as initializing spatial and temporal fishing closure.
\end{abstract}

Keywords: shark fisheries management; sharks immigration; fishing pressure; GLM; abundance indices; standardized CPUE

\section{Introduction}

Sharks play an important role within food-webs, and a reduction in the population size of large sharks can initiate trophic cascades through top-down effects [1-4]. In recent decades, widespread exploitation and habitat degradation have resulted in a substantial decline in shark populations [1,3,5-7]. Hence, a quarter of their species is being threatened with extinction based on the International Union for Conservation of Nature (IUCN) conservation status [8].

One of the most harvested species is silky shark (Carcharhinus falciformis), a pelagic shark that is commonly found in the coastal warm-temperate and tropical regions $[9,10]$. This species is caught by both coastal targeted fisheries and as a major bycatch species in the tuna fisheries. The level of silky shark's fishing mortality is estimated to have depleted the total stock biomass by $70 \%$ from the 
theoretical virgin stock biomass, which is an indication of considerable overfishing [11]. The total catch of the silky shark, as reported to the United Nations Food and Agriculture Organization (FAO), increased from 1990 to early 2000, but then it dramatically decreased after 2000, and in 2014 became less than one fifth from the production in 2000 [12]. Due to international concern, regarding the sustainability of commercial exploitation, silky shark was then listed in Appendix II of the Convention on International Trade of Endangered Species of Wild Fauna and Flora (CITES) in 2016 [13].

Silky sharks were caught in almost all Indonesian waters, including in the Indian Ocean. From 2005 to 2015, the total production of sharks fluctuated between 2500 tons/year and 6700 tons/year, and one-fifth were dominated by Carcharhinidae [14]. Cilacap and Tanjung Luar are known as shark fishery hotspots in Indonesia [15]. Cilacap is located in Southern Java Island and Tanjung Luar is located in eastern Lombok Island, and both of the fishing ports are conterminous with the Indian Ocean. Vessels from these fishing ports commonly fished tuna and sharks in the eastern Indian Ocean that was defined as part of the Indonesia Fisheries Management Area (FMA) 573.

As one of the most common shark species in Indonesian waters, the silky shark dominated the total sharks landed in Tanjung Luar by contributing about 43\% in 2012 [15], and more than 30\% from 2014 to $2016[16,17]$. While in Cilacap, silky sharks contributed between $3 \%$ and $18 \%$ of the total shark catches in the tuna longline and gillnet fisheries from 2006 to 2013 [15].

Information about the population and abundance of silky sharks in the Indian Ocean is currently limited $[10,18,19]$. Since it is crucial for fisheries management, we have to consider several factors for estimating silky shark populations and abundance. Abundance calculations are a common fishery indicator, especially where catch and effort data are used to generate an abundance index based on estimates of relative biomass change [20]. Recently, more advanced statistical methods have also been used to developed stock assessment models (e.g., general linear models, general additive models) [21]. We therefore approached the catch-per-unit-effort (CPUE) by adapting the two-step delta-General Linear (Mixed) Model [22]. This research aims to update the abundance of the silky shark in the eastern Indian Ocean (Indonesian FMA 573) and identify the factors that may influence the abundance using advanced statistical methods based on monthly port sampling data. This information can be used as a baseline for fisheries management.

\section{Result}

\subsection{Fishing Catches and Trips}

Between 2015-2016, landed silky sharks increased from 1881 individuals (24 and 1857 in Cilacap and Tanjung Luar, respectively) to 2952 (18 and 2934 in Cilacap and Tanjung Luar, respectively) individuals. However, the number of shark fishing trips did not significantly increase; there were 351 and 356 trips in 2015 and 2016, respectively. Meanwhile, the number of successful trips, defined as a trip where at least one silky shark was caught, significantly increased from 197 trips in 2015 (10 from Cilacap and 187 from Tanjung Luar) to 413 trips in 2016 (22 from Cilacap and 391 from Tanjung Luar).

\subsection{Catches' Composition and Size}

Silky sharks caught in 2015 consisted of 1183 females and 1011 males. While in 2016, 1734 females and 1217 males were landed. The 95th percentile of the female total length caught in 2015 was $245 \mathrm{~cm}$, and the male was $239.5 \mathrm{~cm}$ (Figure 1). The 95th percentile of the female total length that was caught in 2016 was $239 \mathrm{~cm}$, while the male was $234 \mathrm{~cm}$ (Figure 1). Small silky sharks $(<150 \mathrm{~cm})$ were caught in all months, while the lowest adult silky sharks $(\geq 200 \mathrm{~cm})$ were observed in February, March, and July (Figure 2). Moreover, small fishing vessels ( $<5$ Gross Tonnage (GT)) caught a wider range of total length than that caught by larger fishing vessel (20-30 GT) (Figure 3). 

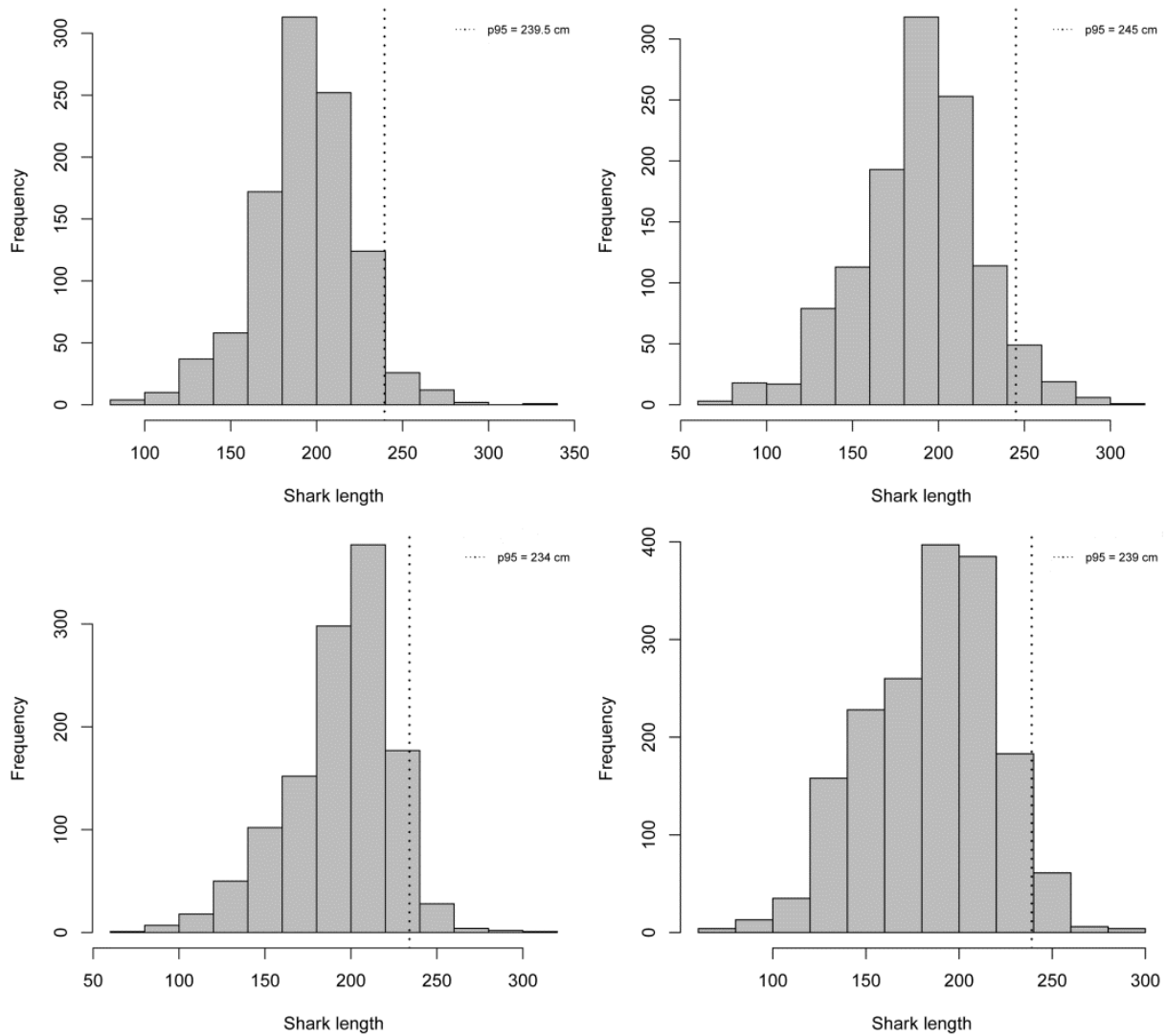

Figure 1. Histograms of total length ( $\mathrm{cm}$ ) for male (left) and female (right) silky sharks landed in 2015 (top) and 2016 (bottom). The 95th percentile of length for each histogram is shown as a dashed vertical line.

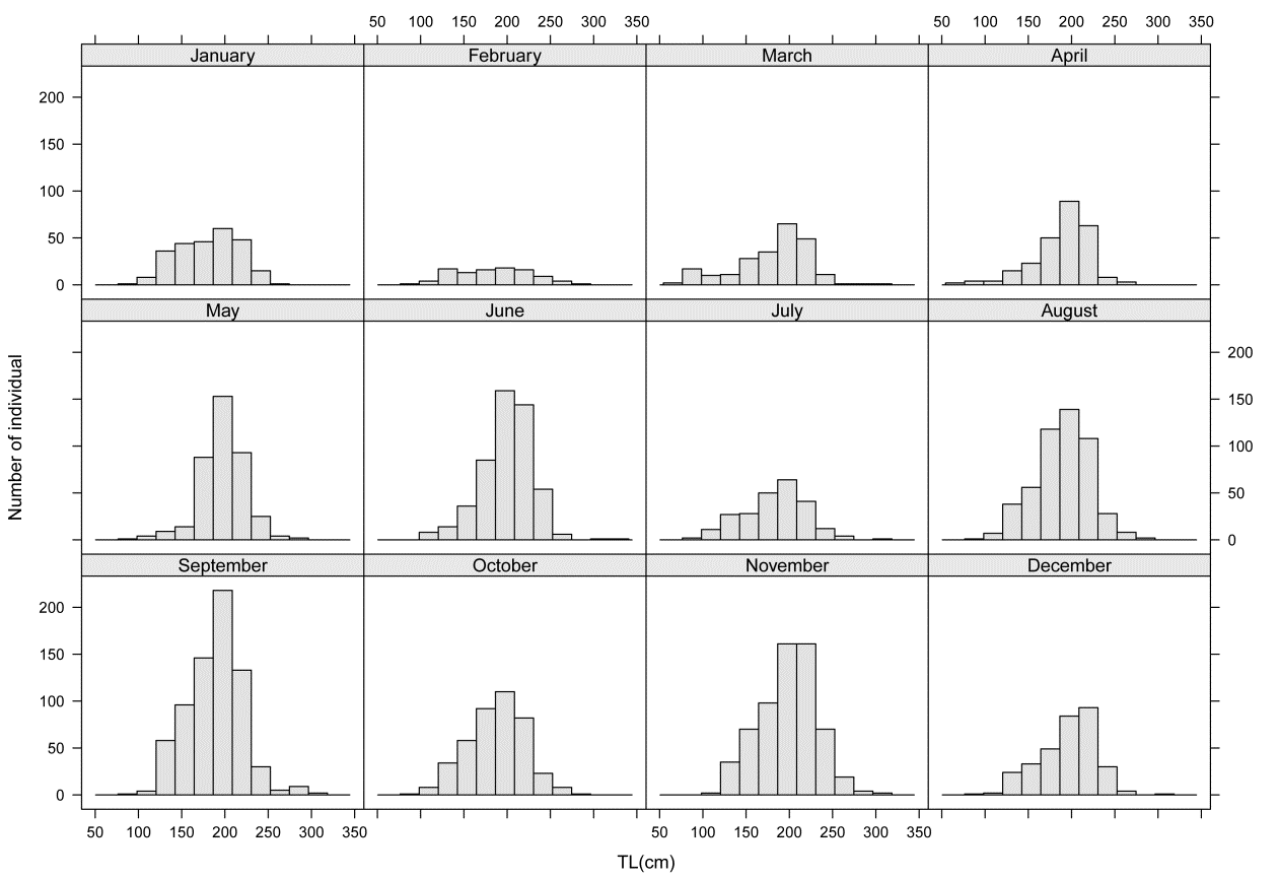

Figure 2. Histograms of landed silky shark total length (TL) (cm) pooled by month for 2015 and 2016. 


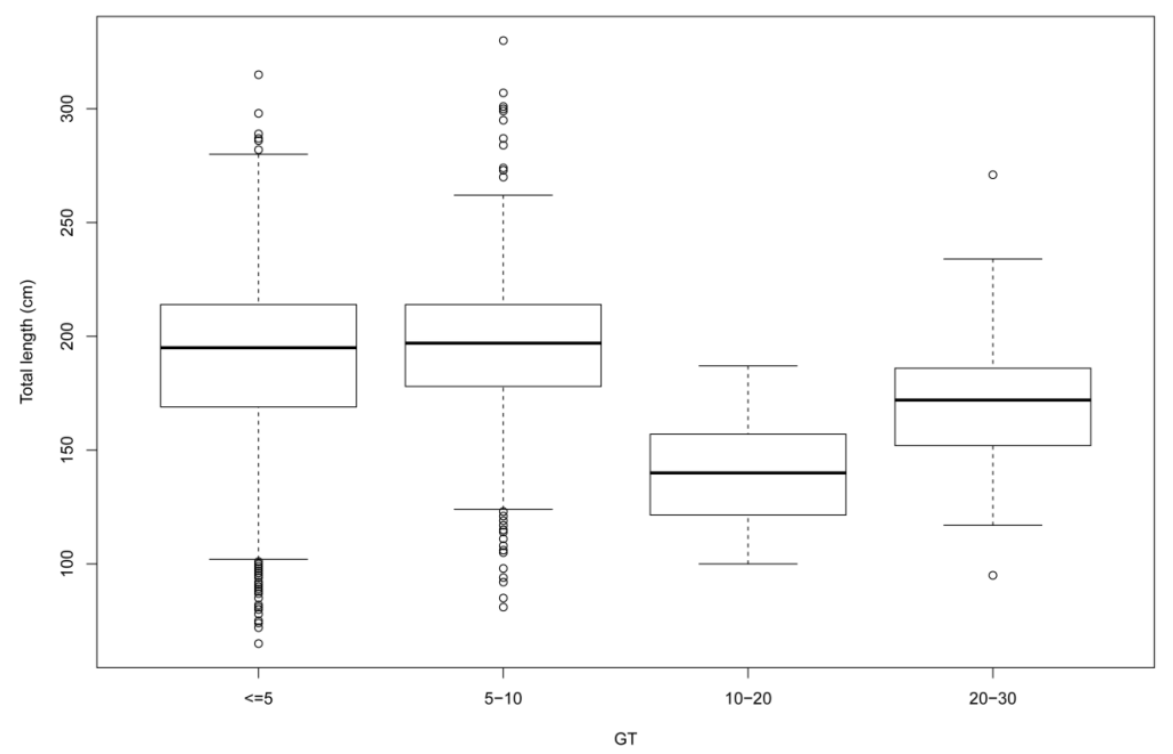

Figure 3. Boxplot of total length of silky sharks landed in Tanjung Luar and Cilacap based on fishing vessel size (Gross Tonnage (GT)).

\subsection{Factors Affecting Fishing Catches}

According to the pattern of the catch data and initial comparison with fishing efforts, we found that month, year, the size of the vessels size (GTs), and effort affected total catch volumes of silky sharks (Figure 4, Table 1); hence, we chose these factors to be tested and set the total effort as offset. We found all factors significantly affected the catch pattern positively. The catch of the surface longline is significantly higher than the catch of the bottom longline $(p<0.001)$, and the higher vessel size resulted in lower catches $(p<0.001)$ compared to the smaller vessel sizes. The catch in 2016 was higher than the catches in $2015(p<0.01)$ (Table 1). For the binomial model, we did not find any significant factor affecting the likelihood of catching silky sharks.
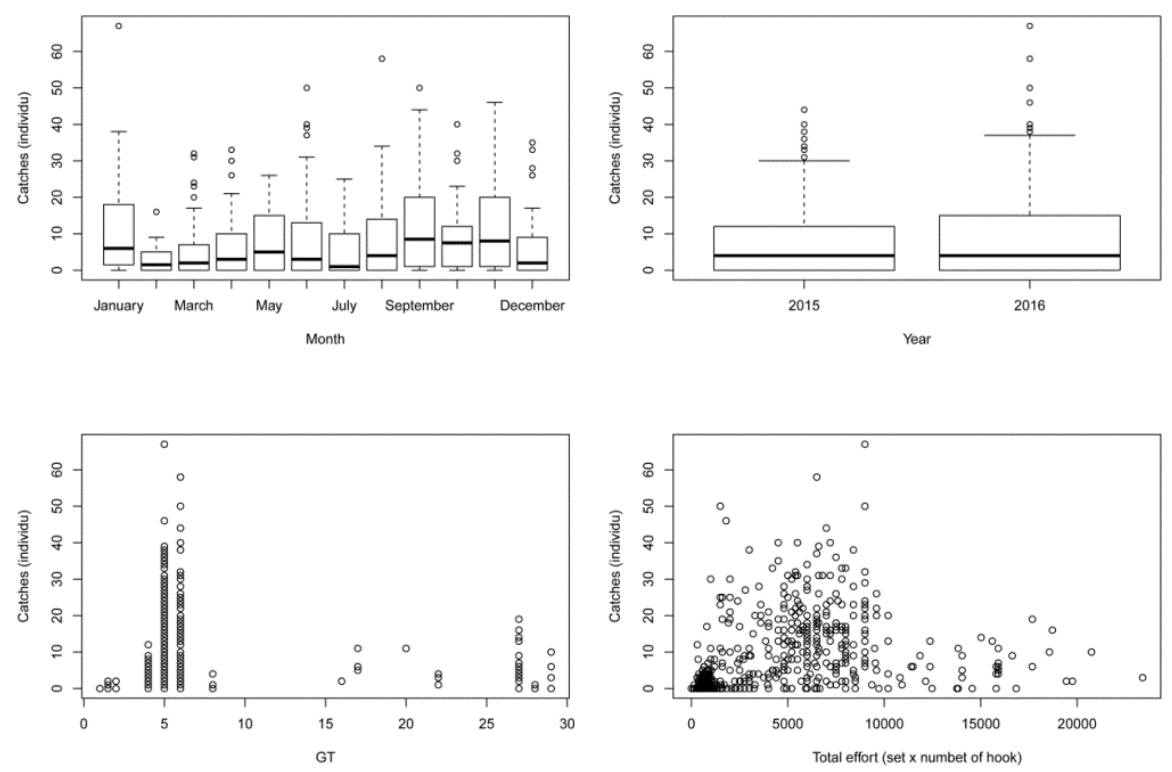

Figure 4. Comparison between sharks caught by different month (top left), by different year (top right), by different vessel sizes (bottom left) and by different total effort (set $x$ number of hook) (bottom right). Data was represented using boxplots for the categorical variables (month and year). 
Table 1. Analysis of variance for the covariates of the best fit models (Equation (1)), which affect the catches of silky shark landed in Tanjung Luar and Cilacap (significant values are highlighted in bold). Df, Degree of freedom; GT, Gross Tonnage.

\begin{tabular}{cccccc}
\hline Covariates & Df Deviance & Residuals & Df Residuals & Deviance & $p$-Value \\
\hline NULL & & & 420 & 649.87 & \\
Year & 1 & 38.849 & 419 & 611.02 & $\mathbf{4 . 5 8} \times \mathbf{1 0}^{-\mathbf{1 0}}$ \\
Month & 11 & 65.416 & 408 & 545.61 & $\mathbf{9} \times \mathbf{1 0}^{-\mathbf{1 0}}$ \\
GT & 1 & 41.188 & 407 & 504.42 & $\mathbf{1 . 3 8} \times \mathbf{1 0}^{-\mathbf{1 0}}$ \\
Gear & 1 & 77.787 & 406 & 426.63 & $<\mathbf{2 . 2} \times \mathbf{1 0}^{-\mathbf{1 6}}$ \\
\hline
\end{tabular}

\subsection{Abundance Indices}

According to the abundance indices, the monthly abundance of silky shark showed a fluctuating pattern. However, the trend in abundance from 2015 to 2016 increased (Figure 5). The lowest abundance in 2015 and 2016 were both in June (6.21 \pm 0.94 and $5.31 \pm 1.48$, respectively). Meanwhile, the highest abundance in both 2015 and 2016 was during September (13.18 \pm 0.35 and 16.09 \pm 0.92 , respectively). The yearly abundance indices of silky sharks in 2015 and 2016 were $8.80 \pm 0.21$ and $10.24 \pm 0.45$, respectively.
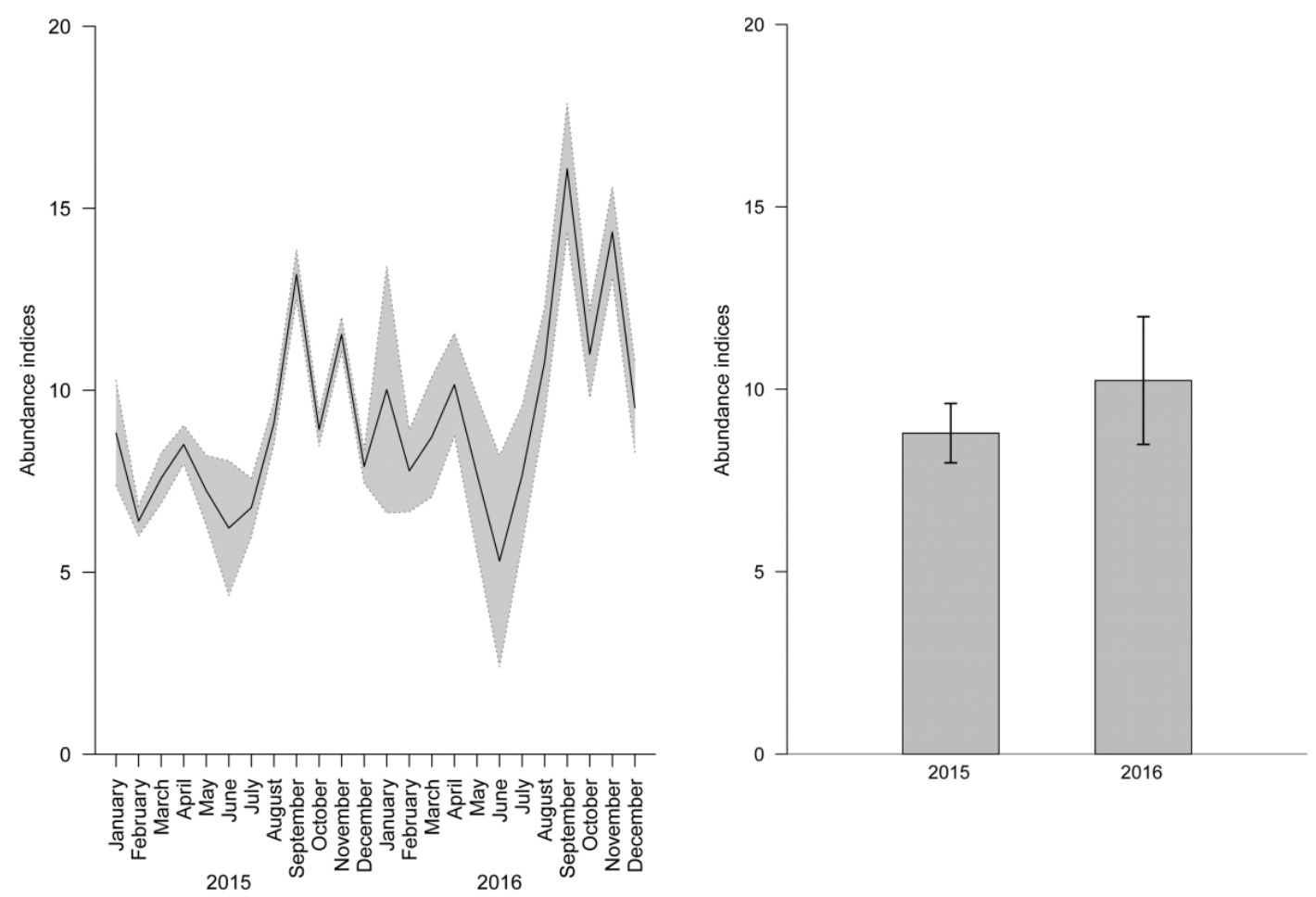

Figure 5. Abundance indices of the silky shark in the Indonesian Fisheries Management Area 573 by month (left) and year (right). Both figures showed mean value and the respective $95 \%$ confidence interval.

\section{Discussion}

The results suggest that standardized CPUE or abundance indices of the silky shark for Cilacap and Tanjung Luar in FMA 573 of Indonesia increased from 2015 to 2016, with a similar body size found in both years. This result is intriguing since it is well known that the silky shark's biomass and abundance has been continued to decline in other parts of its range, including the Pacific Ocean [11] and Gulf of Mexico [23]. Currently, there is no available quantitative stock assessment or basic fishery indicator for the silky shark in the Indian Ocean, therefore the stock status is uncertain [18]. Up until 
recently, there has been no recorded activity specifically for silky sharks in Indonesia. The national data is currently available up to family level (Carcharhinidae), therefore we cannot directly compare this data with our findings. Generally, Carcharhinidae production has decreased since 2013 in Indonesia [24]. Our study, which is the first quantitative analysis of silky shark abundance in our study sites, is therefore valuable; this data also provides important information to describe the population status of silky sharks in the eastern Indian Ocean. According to the IUCN red list, this species status was changed from Near Threatened in 2016 to Vulnerable in 2017 [10]. This is reflected, for example, by Anderson and Juaharee [25], in which $90 \%$ of fishers in Maldives noticed that there are currently 50-90\% fewer silky sharks compared to 20 years ago, and that their sizes were decreasing as well.

To explain our findings, a plausible explanation for the seasonal variation in silky shark CPUE is migration and reduced fishing pressure (see Peterson et al. [26], Curtis et al. [27]). According to the local shark fisher knowledge, gained from discussion, they change their specific fishing ground within FMA 573 according their knowledge on silky shark migration patterns. From April to July, shark fishers in West Nusa Tenggara usually fish near Makassar Strait and Flores Sea (northern areas). This corresponds with lower silky shark abundance and fewer adult silky sharks. Simeon [28] also found that a high abundance of immature silky sharks was found in the Makassar Strait from May to July, while a high abundance of pregnant silky sharks was found in the Bali Strait in December. Cadena-Cardenas [29] identified the migration pattern of adult silky sharks and suggest they return seasonally to feed and reproduce in shelf waters. Other research showed that silky sharks swim towards higher latitudes and deeper waters in a particular season [11,30]. It is therefore plausible that adult sharks migrate to the eastern Indian Ocean in particular months (i.e., August-November, see Figure 1), and it might serve as a plausible explanation towards the silky shark's abundance. Additionally, immature silky sharks were recorded all year in FMA 573. This suggests that this area is a silky shark nursery ground with regular recruitment. A nursery ground of different shark species has been found in the same province [31]. Unfortunately, no specific research has been conducted to study the nursery ground of the silky shark.

Higher catches of immature silky sharks were also associated with smaller shark fishing vessels (i.e., up to 10 GT, see Figure 2). These vessels tend to operate in coastal areas, and previous research shows that juvenile and immature silky sharks tend to swim in the coastal areas (see Bonfil [30]), which explains why they are more likely to be caught by smaller fishing vessels. Larger fishing vessels (i.e., >10 GT) operate in fishing grounds at least 12 nautical miles from the coast, and tend to catch specific length silky sharks. Silky sharks can be found in the continental and insular shelves, slopes, and even offshore waters, and are also caught in oceanic waters of all tropical oceans, where the larger sizes are known as pelagic-oceanic with a wider and higher swimming layer $[9,30,32,33]$. As a pelagic species, most silky sharks were caught by surface longline rather than bottom longline (see Compagno [9], Bonfil [30], Bonfil et al. [34], Henderson et al. [35]).

Fishing pressure in Indonesia has significantly declined since the Minister of Marine Affairs and Fisheries released a new policy in 2014 combating illegal unreported and unregulated fishing. This policy banned foreign fishing vessels and transshipment at sea, with the public sinking of several illegal vessels [36]. Additionally, the minister released a moratorium on new fishing vessel permits $[37,38]$. The new policy significantly reduced the recorded number of boats and total hours at sea per month [36], including for domestic fishing vessels [39]. The fishing gear most impacted by the new policy was the tuna longline, which declined by $44 \%$ in 2015, and followed by purse seine [39]. Sharks are commonly taken as incidental catch or bycatch by tuna fishing vessels [40,41], therefore the decline of tuna fishing vessels may have reduced fishing pressure on silky sharks, leading to a higher abundance in the Indian Ocean in 2015.

Greater abundance of silky sharks in 2016 than in 2015 in Tanjung Luar and Cilacap is therefore not necessarily good news for the silky shark population. After being under pressure by tuna fishing vessels in the Indian Ocean, the silky sharks are now increasingly taken by smaller fishing vessels, which are also catching high numbers of immature silky sharks. This indicates a high juvenile mortality $[20,42,43]$. 
This increase is likely to be related to their changing spatial distribution. This also implies the necessity of long-term observations of the silky shark population to enable us in extrapolating the real trend of its abundance.

Despite increasing international concern about the depletion of shark populations globally, including in Indonesia [8,44,45], practical fisheries management measures still need to be implemented to sustain shark populations. In principle, fisheries management should aim to regulate the intensity of fishing efforts in order to obtain the optimal catch [46]. It is recognized that the Government of Indonesia has been introducing efforts to regulate the catch of larger fishing vessels ( $>30$ GT) by prohibiting catching thresher shark and pregnant sharks (Minister of Marine Affairs and Fisheries Regulation, No. PER.30/MEN/2012 and No. PER.11/MEN/2016). As mentioned previously, the new policies of the Indonesian Government also affect the abundance of silky shark. To complete the existing policies for sustainability of the silky shark, the Government of Indonesia needs to regulate fishing efforts by limiting the number of boats/licenses, number of trips, or fishing gear (e.g., number of hook or length of net), and exert an open-close season (see Dharmadi et al. [44]).

\section{Methods}

\subsection{Site}

This research was conducted in the Cilacap Fishing Port and Tanjung Luar Fishing Port (Figure 6). Generally, sharks in Indonesia were caught both as targeted and by-catch. Targeted fishery occurs in a small-scale fishery (vessel size less than 30 GT, e.g., Tanjung Luar coastal fishing port), while by-catch occurs in a commercial fishery (vessel size larger than 30 GT, e.g., Cilacap Ocean fishing port). At both sites, sharks were landed as whole bodies and none were discarded since all parts are valuable. Cilacap fishery is dominated by a tuna fishery and silky sharks were caught as by-catch. Since both fisheries landed whole-bodied sharks, it was possible for us to collect the data necessary for our analysis. Fishers from Cilacap usually fish in Indian Ocean South of Java, while Tanjung Luar's fishers usually fishing in the southern Lombok down to northern Australia. Southern part of Java, Bali, West Nusa Tenggara, and East Nusa Tenggara are designated as Indonesian Fisheries Management Area (FMA) 573.

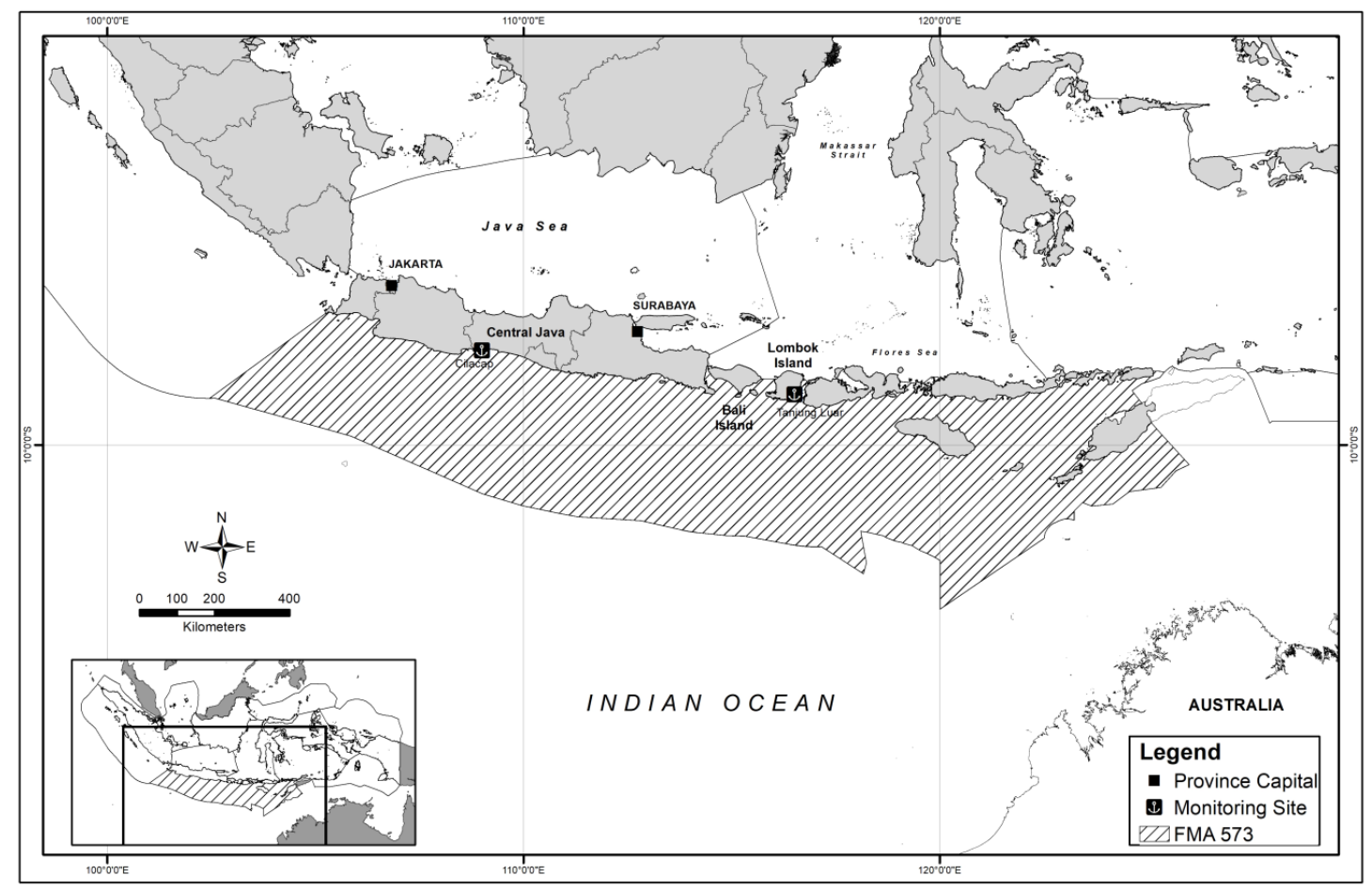

Figure 6. Fishing ground and fishing base in FMA 573. 


\subsection{Data Collection}

Monthly enumeration was conducted in the selected sites during 2015-2016 by a well-trained enumerator. Data collected from longline vessels in both areas included fishing effort or fishing techniques (i.e., gross tonnage, deployment day, and time) that usually influence catches (count number) and catch composition (i.e., species, length, sex) (Table 2).

Table 2. Collected data from Cilacap and Tanjung Luar fishing ports.

\begin{tabular}{cccc}
\hline Item & Measured Variable & Type of Data & Description \\
\hline Fishing techniques & Year & Categorical & Year of trip (2015-2016) \\
& Month & Categorical & Month of trip (January-December) \\
& Date & Categorical & Ship's overall internal volume \\
& Gross tonnage & Numeric & Fishing gear used \\
& Fishing gear & Categorical & Number of times primary fishing gear was deployed \\
& Deployment days & Numeric & Number of hook which used in longline \\
& Number of hook & Numeric & Total length \\
Catch composition & Length & Numeric & Female and male \\
& Sex & Categorical & Referring to White et al. [47] \\
& Species & Categorical & \\
\hline
\end{tabular}

\subsection{Analysis}

We used a simple descriptive statistic to compare the silky shark's catch composition between 2015 and 2016. To identify factors affecting CPUE, we did an initial comparison between the catch and recorded fishing techniques, and then used linear models (LM), generalized linear square (GLS) (package nlme [48]), and a general linear model (GLM) (package MASS [49]) to find the best model to explain variations in the data. Based on the normality of data distribution and heterogeneity of residuals, we found that the GLM negative binomial (GLM NB) was the best model (Table 3) with the following explanatory factors; month, year, the size of the vessels (GTs), type of gear (gear), and transformed total effort (see Campbell [22] and Pratama et al. [50]). Total effort was calculated by multiplying the deployment days with the number of hooks and transformed using $\log 10$.

We estimated the standardized CPUE by adopting the two-step delta-general linear models [22]. This approach consisted of two stages: (1) the calculation of the size of successful catch (Equation (1)), followed by (2) the calculation of the successful catch probability using a best fitted model from the GLM NB (Equation (2)) [22]. We then estimated the overall mean catch rate as the combination of the parameters from the distributions of the non-zero catch rates and the probability of a successful catch [22]. We estimated and multiplied the mean of positive catches using our best model of the GLM negative binomial (Equation (1)) and the probability of successful catches using the binomial model (Equation (2)).

GLM NB model (Table 3, model No. 9):

$$
\text { Shark catch count } \approx \text { year }+ \text { month }+\mathrm{GT}+\text { gear }+ \text { offset }(\log 10(\text { total effort }))
$$

Binomial model (Binomial model test on Equation (1)):

$$
\text { Probability of successful catch } \approx \text { year }+ \text { month }+\mathrm{GT}+\text { gear }+ \text { total effort }
$$

A candidate model set was defined (Table 3), and model selection using the Akaike Information Criteria (AIC) was conducted. The GLM negative binomial model was chosen based on the over-dispersal and the lowest AIC value (Table 3). To estimate the probability of successful catches and the mean of positive catches, we used the mean utilized fishing vessel gross tonnage and the mean of the total effort as the standardized value using the lsmeans package [51]. Errors of abundance indices were calculated by multiplying the error of the probability of successful catches and the error of the 
mean of positive catches (see Shono [52]). All statistical tests were conducted using the R programming language [53].

Table 3. Candidate model set tested to identify important explanatory variables for the silky shark catch-per-unit-effort (CPUE). The best-fitted model is highlighted in bold. The best fitted model in the generalized linear model negative binomial (GLM NB) equation (Equation (1)) is further used for the binomial model (Equation (2)).

\begin{tabular}{|c|c|c|c|c|}
\hline No & Models & Family & Model & AIC \\
\hline 1 & Linear Model & $\mathrm{N} / \mathrm{A}$ & Catch $\sim$ Month + GT + Year + total effort & 3036 \\
\hline 2 & Generalized Least Squares & $\mathrm{N} / \mathrm{A}$ & Catch $\sim$ Month + GT + Year + total effort & 3022 \\
\hline 3 & Generalized Least Squares & $\mathrm{N} / \mathrm{A}$ & $\begin{array}{c}\text { Catch } \sim \text { Month }+ \text { GT }+ \text { Year }+ \text { total effort } \\
\text { varIdent(form }=\sim 1 \text { । Month) }\end{array}$ & 2989 \\
\hline 4 & Generalized Least Squares & $\mathrm{N} / \mathrm{A}$ & $\begin{array}{c}\text { Catch } \sim \text { Month }+ \text { GT }+ \text { Year + total effort } \\
\text { varIdent(form }=\sim 1 \text { । Year) }\end{array}$ & 2998 \\
\hline 5 & Generalized Linear Model & Poisson & Catch $\sim$ Month + Year + GT + total effort & 3605 \\
\hline 6 & Generalized Linear Model & $\begin{array}{l}\text { Poisson with } \\
\text { overdispersal }\end{array}$ & Catch $\sim$ Month + Year + GT + total effort & $\mathrm{N} / \mathrm{A}$ \\
\hline 7 & Generalized Linear Model & Negative-Binomial & Count $\sim$ Month + Year + total effort & 2873 \\
\hline 8 & Generalized Linear Model & Negative-Binomial & Catch $\sim$ Month + Year + GT + total effort & 2801.579 \\
\hline 9 & Generalized Linear Model & Negative-Binomial & $\begin{array}{c}\text { Catch } \sim \text { Year + Month + GT + Gear + } \\
\text { offset(log10(total effort) })\end{array}$ & 2687.649 \\
\hline
\end{tabular}

Author Contributions: Methodology, B.M.S.; U.M.; D., and I.Y.; Validation, B.M.S. and U.M.; Formal Analysis, B.M.S.; U.M.; E.M., M.I., and I.Y.; Data Curation, B.M.S.; Writing-Original Draft Preparation, B.M.S.; E.M., and M.I.; Writing-Review \& Editing, F.; D.; A.P.P.; U.M., and I.Y.; Supervision, I.Y. and E.M.

Funding: This research was funded by the Darwin initiative project reference 22-008 and the Center for Fisheries Research, Indonesia Ministry of Marine Affairs and Fisheries.

Acknowledgments: We wish to acknowledge the support provided by fishers and enumerators in Tanjung Luar and Cilacap for their great cooperation during the fieldwork. We also thank the Darwin Initiative for funding the data collection activity. We would also thank Harry Alastair and Juan Carlos, for helping with the R code and data processing, and Hollie Booth for carefully reading the manuscript, and providing useful inputs, and the anonymous reviewers for their constructive comments.

Conflicts of Interest: The authors declare no conflicts of interest.

\section{References}

1. Stevens, J.D.; Bonfil, R.; Dulvy, N.K.; Walker, P.A. The effects of fishing on sharks, rays and chimaeras (chondrichthyans) and implications for marine ecosystems. ICES J. Mar. Sci. 2000, 57, 476-494. [CrossRef]

2. Myers, R.A.; Baum, J.K.; Shepherd, T.D.; Powers, S.P.; Peterson, C.H. Cascading effects of the loss of apex predatory sharks from a coastal. Science 2007, 315, 1846-1850. [CrossRef] [PubMed]

3. Ferretti, F.; Worm, B.; Britten, G.L.; Heithaus, M.R.; Lotze, H. Patterns and ecosystem consequences of shark declines in the ocean. Ecol. Lett. 2010, 13, 1055-1071. [CrossRef] [PubMed]

4. Bornatowski, H.; Braga, R.R.; Bilhoa, V.; Correa, M.F. Feeding ecology and trophic comparisons of six shark species in a coastal ecosystem off southern Brazil. J. Fish Biol. 2014, 85, 246-263. [CrossRef] [PubMed]

5. Hutchings, J.A. Collapse and recovery of marine fishes. Nature 2000, 406, 882-885. [CrossRef] [PubMed]

6. Simpfendorfer, C.A.; Hueter, R.E.; Bergman, U.; Connett, S.M.H. Results of a fishery-independent survey for pelagic sharks in the western North Atlantic, 1977-1994. Fish. Res. 2002, 55, 175-192. [CrossRef]

7. Dudley, S.F.J.; Simpfendorfer, C.A. Population status of 14 shark species caught in the protective gillnets off KwaZulu-Natal beaches, South Africa, 1978-2003. Mar. Freshw. Res. 2006, 57, 225-240. [CrossRef] 
8. Dulvy, N.K.; Fowler, S.L.; Musick, J.A.; Cavanagh, R.D.; Kyne, P.M.; Harrison, L.R.; Carlson, J.K.; Davidson, L.N.K.; Fordham, S.V.; Francis, M.P.; et al. Extinction risk and conservation of the world's sharks and rays. eLife 2014, 3, e00590. [CrossRef] [PubMed]

9. Compagno, L.J.V. FAO Species Catalogue. Sharks of the World; Food and Agriculture Organization of the United Nations: Rome, Italy, 1984; Volume 4.

10. Rigby, C.L.; Sherman, C.S.; Chin, A.; Simpfendorfer, C. Carcharhinus falciformis, Silky Shark. IUCN Red List Threat. Spec. 2017, e.T39370A117721799. [CrossRef]

11. Rice, J.; Harley, S. Updated stock assessment of silky sharks in the western and central pacific ocean. In Proceedings of the Scientific Committee Ninth Regular Session, Pohmpei, Federated States of Micronesia, 6-14 August 2013. WCPFC-SC9-2013/SA-WP-03.

12. Food and Agriculture Organization of the United Nations. Available online: http://www.fao.org/fishery/ species/2021/en (accessed on 20 April 2017).

13. CITES. Proposal for amendment of Appendices I and II. In Seventeenth meeting of the Conference of the Parties, Johannesburg, South Africa), 24 September-October 2016; CoP17 Prop 42. Available online: https: / / cites.org/sites/default/files/eng/cop/17/prop/060216/E-CoP17-Prop-42.pdf (accessed on 8 June 2018).

14. Ministry of Marine Affairs and Fisheries. Fisheries Statistics Data; MMAF: Jakarta, Indonesia, 2015.

15. Fahmi; Dharmadi. Pelagic shark fisheries of Indonesia's Eastern Indian ocean fisheries management region. Afr. J. Mar. Sci. 2015, 37, 259-265. [CrossRef]

16. Simeon, B.M.; Agustina, S.; Muttaqin, E.; Ichsan, M.; Yulianto, I. Technical Report Sharks and Rays Fisheries in West Nusa Tenggara; Wildlife Conservation Society: Bogor, Indonesia, 2017.

17. Sentosa, A.A.; Dharmadi, D. Lombok catch and relative abundance of some sharks landing in Tanjung Luar. Widyariset 2017, 3, 131-142. [CrossRef]

18. IOTC. Status of the Indian Ocean Silky Shark (FAL: Carcharhinus Falciformis); IOTC: Victoria Mahé, Seychelles, 2016.

19. Poisson, F.; Filmalter, J.D.; Vernet, A.L.; Dagorn, L. Mortality rate of silky sharks (Carcharhinus falciformis) caught in the tropical tuna purse seine fishery in the Indian Ocean. Can. J. Fish. Aquat. Sci. 2014, 71, 795-798. [CrossRef]

20. Maunder, M.N.; Starr, P.J. Fitting fisheries models to standardised CPUE abundance indices. Fish. Res. 2003, 63, 43-50. [CrossRef]

21. Campbell, R.A. CPUE Standardisation and the construction of indices of stock abundance in a spatially varying fishery using general linear models. Fish. Res. 2004, 70, 209-227. [CrossRef]

22. Campbell, R.A. Constructing stock abundance indices from catch and effort data: Some nuts and bolts. Fish. Res. 2015, 161, 109-130. [CrossRef]

23. Baum, J.K.; Myers, R.A. Shifting baselines and the decline of pelagic sharks in the Gulf of Mexico. Ecol. Lett. 2004, 7, 135-145. [CrossRef]

24. Ministry of Marine Affairs and Fisheries. Fisheries Statistics Data; Directorate General of Capture Fisheries of MMAF: Jakarta, Indonesia, 2016; 325p.

25. Anderson, R.C.; Juaharee, R. Opinions Count: Declines in Abundance of Silky Sharks in the Central Indian Ocean Reported by Maldivian Fishermen. Indian Ocean Tuna Commission. 2009. IOTC2009-WPEB-08(2009). Available online: http://iotc.org/sites/default/files/documents/proceedings/2009/wpeb/IOTC2009WPEB-08.pdf (accessed on 27 February 2018).

26. Peterson, C.D.; Parsons, K.T.; Bethea, D.M.; William, B.D., III; Latour, R.J. Community interactions and density dependence in the southeast United States coastal shark complex. Mar. Ecol. Prog. Ser. 2017, 579, 81-96. [CrossRef]

27. Curtis, T.H.; McCandless, C.T.; Carlson, J.K.; Skomal, G.B.; Kohler, N.E.; Natanson, L.J.; George, H.B.; Hoey, J.J.; Pratt, H.L., Jr. Seasonal distribution and historic trends in abundance of white sharks, Carcharodon carcharias, in the western north Atlantic Ocean. PLoS ONE 2014, 9, e99240. [CrossRef] [PubMed]

28. Simeon, B.M. Kondisi dan Dampak Penangkapan Hiu Kejen. (Carcharhinus falciformis) Terhadap Ekosistem: Kasus Perikanan hiu di Muncar. Master Thesis, Graduated School, Bogor Agricultural University, Bogor, Indonesia, 30 June 2016.

29. Cadena-Cardenas, L. Biologia Reproductiva de Carcharhinus falciformis (Chondrichtyes: Carcharhiniformes: Carcharhinidae), en el Golfo de California. Bachelor's Thesis, Departemento de Biologia Marina, Universidad Autonoma de Baja California Sur, La Paz, Mexico, 2001. 
30. Bonfil, R. The Biology and Ecology of the Silky Shark, Carcharhinus falciformis. In Sharks of the Open Ocean: Biology, Fisheries and Conservation; Blackwell Publishing: Oxford, UK, 2008. [CrossRef]

31. Simeon, B.M.; Muttaqin, E.; Ichsan, M.; Tarigan, S.; Hernawati; Yulianto, I. Technical Report: Critical Habitat of Sharks and Rays in Lunyuk, Sumbawa, West Nusa Tenggara Province; Wildlife Conservation Society-Indonesia Program: Bogor, Indonesia, 2018.

32. Filmalter, J.D.; Dagorn, L.; Cowley, P.D.; Taquet, M. First descriptions of the behavior of silky sharks, Carcharhinus falciformis, around drifting fish aggregating devices in the Indian Ocean, using acoustic telemetry. Bull. Mar. Sci. 2011, 87, 325-337. [CrossRef]

33. Last, P.R.; Stevens, J.D. Sharks and Rays of Australia; CSIRO: Victoria, Australia, 1984.

34. Bonfil, R.; Mena, R.; de Anda, D. Biological Parameters of Commercially Exploited Silky Sharks, Carcharhinus Falciformis, from the Campeche Bank, Mexico; NOAA Technical Report NMFS; National Marine Fisheries Service: Silver Spring, MD, USA, 1993.

35. Henderson, A.C.; Mcllwain, J.L.; Al-Oufi, H.S.; Al-Sheile, S.; Al-Abri, N. Size distributions and sex ratios of sharks caught by Oman's artisanal fishery. Afr. J. Mar. Sci. 2009, 31, 233-239. [CrossRef]

36. Cabral, R.B.; Mayorga, J.; Clemence, M.; Lynham, J.; Koeshendrajana, S.; Muawanah, U.; Nugroho, D.; Anna, Z.; Ghofar, A.; Zulbainarni, N.; et al. Rapid and lasting gains from solving illegal fishing. Nat. Ecol. Evol. 2018, 2, 650-658. [CrossRef] [PubMed]

37. Nurlaili, R.M.; Hikmayani, Y. Policy impact moratorium on business fisheries sector in Bitung. J. Kebijak. Sosek Kelaut. Perikan. 2016, 6, 145-152. [CrossRef]

38. Rahmayanti, A.Z.; Cahyono, B.D.; Nadjib, M. Implikasi kebijakan moratorium terhadap sektor perikanan di Bitung. J. Ekon. Pembang. 2017, 25, 1-14. [CrossRef]

39. Hikmayani, Y.; Rahadian, R.; Nurlaili, N.; Muhartono, R. Efektivitas pemberlakuan kebijakan moratorium kapal eks asing dan transhipment terhadap kinerja usaha penangkapan ikan. J. Kebijak. Sos. Ekon. Kelaut. Perikan. 2015, 5, 101-112. [CrossRef]

40. Barker, M.J.; Schluessel, V. Managing global shark fisheries: Suggestions for prioritizing management strategies. Aquat. Conserv. Mar. Freshwat. Ecosyst. 2005, 15, 325-347. [CrossRef]

41. Romanov, E.V. Bycatch in the tuna purse-seine fisheries of the western Indian Ocean. Fish. Bull. 2002, 100, 90-105.

42. Beerkircher, L.; Shivji, M.; Cortes, E. A Monte Carlo demographic analysis of silky shark (Carcharhinus falciformis): Implication of gear selectivity. Fish. Bull. 2002, 101, 168-174.

43. Hutchinson, M.R.; Itano, D.G.; Muir, J.A.; Holland, K.N. Post-release survival of juvenile silky sharks captured in a tropical tuna purse seine fishery. Mar. Ecol. Prog. Ser. 2015, 521, 143-154. [CrossRef]

44. Dharmadi; Fahmi; Satria, F. Fisheries management and conservation of sharks in Indonesia. Afr. J. Mar. Sci. 2015, 37, 249-258. [CrossRef]

45. Lack, M.; Sant, G. Trends in World Shark Catch, Production and Trade, 1990-2003. Australian Government Department of the Environment and Heritage and TRAFFIC Oceania. 2006. Available online: http: / www. traffic.org/fish/ (accessed on 13 March 2015).

46. Purwanto, J. Status and management of the Java Sea fisheries. In Assessment Management and Future Directions for Coastal Fisheries in Asian Countries; Silvestre, G., Garces, L., Stobutzki, I., Eds.; World Fish Conference Proceeding; World Fish Center: Penang, Malaysia, 2003; Volume 67, pp. 1-120.

47. White, W.T.; Last, P.R.; Stevens, J.D.; Yearsley, G.K.; Fahmi; Dharmadi. Economically Important Sharks E Rays of Indonesia; Australian Centre for International Agricultural Research: Canberra, Australia, 2006.

48. Pinheiro, J.; Bates, D.; DebRoy, S.; Sarkar, D.; R Core Team. Nlme: Linear and Nonlinear Mixed Effects Models. R Package Version 3.1-131. 2017. Available online: https:/ CRAN.R-project.org/package=nlme \ T1 \textgreater \{\} (accessed on 3 November 2017).

49. Venables, W.N.; Ripley, B.D. Modern Applied Statistics with S, 4th ed.; Springer: New York, NY, USA, 2002; ISBN 0-387-95457-0.

50. Pratama, M.A.D.; Hapsari, T.D.; Triarso, I. Factors affecting the production of purse seine unit in fishing base Muncar fishing port Banyuwangi, East Java. J. Saintek Perikan. 2016, 11, 120-128.

51. Lenth, R.V. Least-Squares Means: The R Package lsmeans. J. Stat. Softw. 2016, 69, 1-33. [CrossRef] 
52. Shono, H. Confidence interval estimation of CPUE year trend in delta-type two-step model. Fish. Sci. 2008, 74, 712-717. [CrossRef]

53. R Core Team. R: A Language and Environment for Statistical Computing; R Foundation for Statistical Computing: Vienna, Austria, 2017. Available online: https:/ /www.R-project.org/ (accessed on 3 November 2017). 